\title{
The Evidence-based Effect of Platelet-rich Fibrin in Osteogenesis: A Systematic Review and Meta-analysis
}

\author{
Mujaddid Idulhaq ${ }^{1 *}$ (D) Ambar Mudigdo², Pamudji Utomo ${ }^{3}$ D Brian Wasita $^{2}$ \\ ${ }^{1}$ Doctoral Program, Faculty of Medicine, Universitas Sebelas Maret, Solo, Indonesia; ${ }^{2}$ Department of Anatomical Pathology, \\ Faculty of Medicine, Universitas Sebelas Maret, Solo, Indonesia; ${ }^{3}$ Department of Orthopedic and Traumatology, Faculty of \\ Medicine, Universitas Sebelas Maret, Prof. Dr. R. Soeharso Orthopedic Hospital, Solo, Indonesia
}

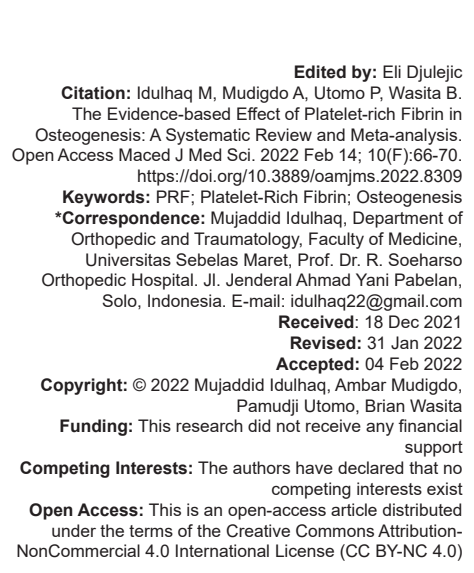

\section{Introduction}

The refinement of bone defects is one of the most frequent regenerative methods involving more than 2 million bone grafts in the global world annually. Bone defects are mainly caused by trauma, congenital anomalies, and tissue resection because of cancer [1]. Even though bone has an exquisite capacity performance in self-repairing, it is still limited, particularly in bridge extensive defects. Despite the advances in the treatment in medicine, autologous bone transplantation is deemed the gold standard to treat bone defects [1]. The transplantation procedure includes harvesting bone derived from other anatomical locations in the patient to be used as a transplantation material in the bone defect site. At present, there is an advanced development in bone repair using biomaterial for augmentation. Different biomaterials have been utilized in dentistry and proven to fill skeletal defects and improve wound healing. The previous materials such as tricalcium phosphate, freeze-dried bone graft, and hydroxyapatite bioactive glass have been commonly used and tested for their effect and significance in healing and regenerating soft and hard tissues [2].

Autologous bone transplantation utilizes the autologous graft for the treatment procedure. Autologous grafts are collected from patients, in which, they are to be used, commonly at the first surgical procedure. Allografts are collected from one patient or individual and they can be utilized for another patient in the same species. A xenograft, the third form of graft, is different from other graft forms because graft material can be used in individuals of different species. Grafts could be gathered from cortical bone, cancellous bone, a combination of the two (corticocancellous graft), or from cartilage (osteochondral) [3]. Grafts treat defect repairment by viable osteoblasts accouterment and their precursors through recruitment of MSCs that discern into osteoblast and chondrocytes (osteoinduction) and by administering new bone formation scaffold (osteoconduction) [3].

Recently, numerous studies have been centralized to study the utilization of platelet-rich fibrin 
(PRF), an autogenous material. PRF provides scaffold osteoconduction and growth factors to prompt patients' cells toward a regenerative response [4]. PRF is a fibrin matrix in which growth factors, platelet cytokines, and cells are cornered and liberated after a specific time [5]. PRF acts as a growth factor and promotes the healing and regeneration of wounds. It is used in dentistry to heal various lesions and regenerate oral and dental tissues [2]. However, the development of PRF utilization, a limited study finds the evidencebased PRF effect on osteogenesis. Therefore, this study aims to summarize the effect of PRF on bone osteogenesis.

\section{Methods}

Data collection and assessment of the methodological quality of each included study referred to the standard method of preferred reporting items for systematic reviews and meta-analysis [6]

\section{Literature search method}

\section{Inclusion criteria}

The studies had to analyze the effect of plateletrich fibrin application with bone osteogenesis (in vitro and in vivo study) and had to be published in English with published between January 2010 and May 2021.

\section{Databases}

Published studies were collected from PubMed. Using text words, medical subject headings (MeSH) and search terms were performed in the article search. The reference list of recaptured articles was assessed manually to identify further research studies relevant to the PRF effect in bone osteogenesis.

\section{Participant}

It was conducted on behalf of clinical trial studies. The studies also utilize either in vitro or in vivo design and it also recruited studies from dentistry and orthopedics studies.

\section{Interventions}

This review highlights platelet-rich fibrin's use with and without combining other grafting materials. The comparison was recorded using the significant outcome marker results such as bone alkaline phosphatase (ALP), RUNX2, OCN, and TRAP.

\section{Critical appraisal}

The selected relevant study was assessed by the primary investigator independently for methodological validity. An expressly designed checklist was employed to examine every study according to the inclusion criteria. Specific articles were not included because of limited information on the PRF outcome with one of the osteogenesis markers. The process of this systematic review was summarized with a PRISMA flow diagram (Figure 1).

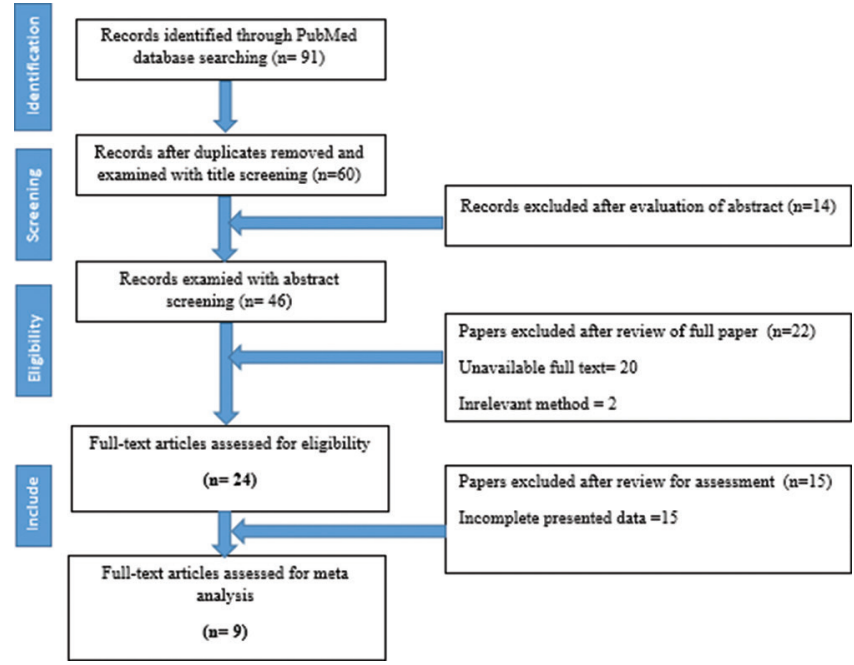

Figure 1: PRISMA flow diagram, summary of search process

\section{Risk bias}

The included studies were assessed for outcome reporting bias by utilizing PRISMA, 2009

\begin{tabular}{|c|c|c|c|c|c|c|c|c|c|c|c|}
\hline \multirow[b]{2}{*}{ Study or Subgroup } & \multicolumn{3}{|c|}{ PRF } & \multicolumn{3}{|c|}{ Control } & \multicolumn{3}{|c|}{ Mean Difference } & \multirow{2}{*}{$\begin{array}{l}\text { Mean Difference } \\
\text { IV, Fixed, } 95 \% \mathrm{CI}\end{array}$} & \\
\hline & Mean & SD & Total & Mean & SD & Total & Weight & IV, Fixed, $95 \% \mathrm{Cl}$ & & & \\
\hline Ghaznavi et al., 2019 & 5.8 & 0.2 & 1 & 5.5 & 0.2 & 1 & $22.5 \%$ & $0.30[-0.25,0.85]$ & & \begin{tabular}{l|l} 
年— \\
\end{tabular} & \\
\hline P. C. Wong et al., 2021 & 3.8 & 0.3 & 2 & 1 & 0.1 & 2 & $35.9 \%$ & $2.80[2.36,3.24]$ & & & 一늠 \\
\hline Song et al., 2018 & 3.7 & 0.3 & 3 & 2.8 & 0.2 & 3 & $41.5 \%$ & $0.90[0.49,1.31]$ & & 一- & \\
\hline Sumida et al., 2019 & 10 & 4 & 4 & 36 & 5.19 & 4 & $0.2 \%$ & $-26.00[-32.42,-19.58]$ & 4 & & \\
\hline Thanasrisuebwong et al., 2020 & 0 & 0 & 0 & 0 & 0 & 0 & & Not estimable & & & \\
\hline Xiaoju Li et al., 2018 & 0 & 0 & 0 & 0 & 0 & 0 & & Not estimable & & & \\
\hline Total $(95 \% \mathrm{Cl})$ & & & 10 & & & 10 & $100.0 \%$ & $1.40[1.14,1.67]$ & & & \\
\hline \multicolumn{9}{|c|}{$\begin{array}{l}\text { Heterogeneity: } \text { Chi }^{2}=130.04, d f=3(P<0.00001) ; I^{2}=98 \% \\
\text { Test for overall effect: } Z=10.47(P<0.00001)\end{array}$} & $\begin{array}{l}-2 \\
\text { Favo }\end{array}$ & $\begin{array}{lll}-1 & 1 & 1 \\
{[\text { Control] }} & \text { Favours [ }\end{array}$ & $\frac{1}{2}$ \\
\hline
\end{tabular}

Figure 2: Forest plot of PRF and ALP 


\begin{tabular}{|c|c|c|c|c|c|c|c|c|c|}
\hline \multirow[b]{2}{*}{ Study or Subgroup } & \multicolumn{3}{|c|}{ PRF } & \multicolumn{3}{|c|}{ Control } & \multicolumn{2}{|r|}{ Mean Difference } & \multirow{2}{*}{$\begin{array}{l}\text { Mean Difference } \\
\text { IV, Fixed, } 95 \% \mathrm{Cl}\end{array}$} \\
\hline & Mean & SD & Total & Mean & SD & Total & Weight & IV, Fixed, $95 \% \mathrm{Cl}$ & \\
\hline Duan et al., 2018 & 7.9 & 1 & 3 & 1 & 0.01 & 3 & $2.1 \%$ & $6.90[5.77,8.03]$ & \multirow{5}{*}{ 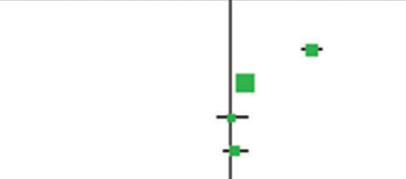 } \\
\hline P. C. Wong et al., 2021 & 3.5 & 0.2 & 5 & 0.9 & 0.3 & 5 & $26.8 \%$ & $2.60[2.28,2.92]$ & \\
\hline Song et al., 2018 & 1.7 & 0.2 & 3 & 1.2 & 0.1 & 3 & $41.7 \%$ & $0.50[0.25,0.75]$ & \\
\hline Sumida et al., 2019 & 1.2 & 0.34 & 4 & 1.1 & 0.34 & 4 & $12.0 \%$ & $0.10[-0.37,0.57]$ & \\
\hline Xiaoju Li et al., 2018 & 1.6 & 0.2 & 2 & 1.4 & 0.2 & 2 & $17.4 \%$ & $0.20[-0.19,0.59]$ & \\
\hline Total $(95 \% \mathrm{Cl})$ & & & 17 & & & 17 & $100.0 \%$ & $1.10[0.93,1.26]$ & 1 \\
\hline \multicolumn{9}{|c|}{$\begin{array}{l}\text { Heterogeneity: } \mathrm{Chi}^{2}=246.60, \mathrm{df}=4(\mathrm{P}<0.00001) ; F^{2}=98 \% \\
\text { Test for overall effect: } Z=13.13(P<0.00001)\end{array}$} & $\begin{array}{ccccc}-4 & -2 & 0 & 2 & 4 \\
\text { Favours [Control] } & \text { Favours [PRF] }\end{array}$ \\
\hline
\end{tabular}

Figure 3: Forest plot of PRF and RUNX2

guidelines. These were examined by contrasting the study objective, intervention, and outcomes. All included studies were categorized it low, high, or unclear bias by the initial analyst regarding reported results. Articles with low bias were only selected to be synthesized and analyzed in quantitative analysis.

\section{Data analysis strategy}

We employed a random-effects model with a restricted maximum likelihood approximate to assess the summary relative risk. The effect of homogeneity across the studies was estimated using $v^{2}$ statistic and quantified by $1^{2}$, showing the total variation of percentage among studies related to heterogeneity than chance.

\section{Results and Discussion}

\section{The effect of PRF in osteogenesis}

It showed that PRF intervention was less effective in osteogenesis than PRF combination with other materials. However, the studies that only employed PRF indicated an inclining number of OPG/ RANK ratio by OPG expression induction, implying PRF enhancement in early-stage osteogenesis with improving osteoblastic differentiation [7]. PRF positively affects the process of wound healing, especially in angiogenesis, in the in vitro coculture [8]. PRF membrane soluble extracts reduced the expression level of Cathepsin K, nuclear factor of activated T-cells (NFATc1), osteoclast marker genes TRAP, osteoclast-associated receptor (OSCAR), and dendritic cell-specific transmembrane protein (DC-STAMP) [9]. Clinical studies reported that PRF's advantages in bone regeneration depend on its combined competency as cell migration, proliferation, and agent of woundhealing, along with its tissue-specific capacity to result in osteoblast differentiation [10].

PRF combined with other materials has revealed better effectiveness in bone regeneration and osteogenesis rather than PRF alone. The use of an $\mathrm{Mg}$ ring enhanced the osteogenic ability and migration capacity of $\mathrm{Mg}$ ions during degradation. Large-pore platelet-rich fibrin (LPRF) combined with $\mathrm{Mg}$ ring showed more effect in repairing long bone defects [11]. Other studies showed that red i-PRF might be advisable for bone rejuvenation because of its capability to induce growth and mobilization of bone regeneration cells without affecting premature mineralization. Moreover, red i-PRF combined with bone substitute material application may be more effective than the yellow i-PRF [12]. Intervention using the combination of BMSCs and PRFr has more significant results in improving osteogenesis, which served as an understanding for further developing a novel therapeutic strategy in treating osteoporosis [13]. Gold nanoparticles to the advanced PRF and fibrin and platelet byproducts could be new substitute strategies to enhance the osteogenesis capacity of the stem cells [14]. PRF transplantation along with rat PDLSCs reported a higher expression of collagen I (COL1A), RUNX2, and osteopontin (Opn) at both 12 and 24 days after surgery. Regarding the histological analysis and micro-computed tomography, more bone formation was found in the PRF + cells group 24 days after surgery. Stereology and histologic examination revealed a higher composition of bone development in the defects treated with PRF mixed $\beta$-TCP compared to the treatment of

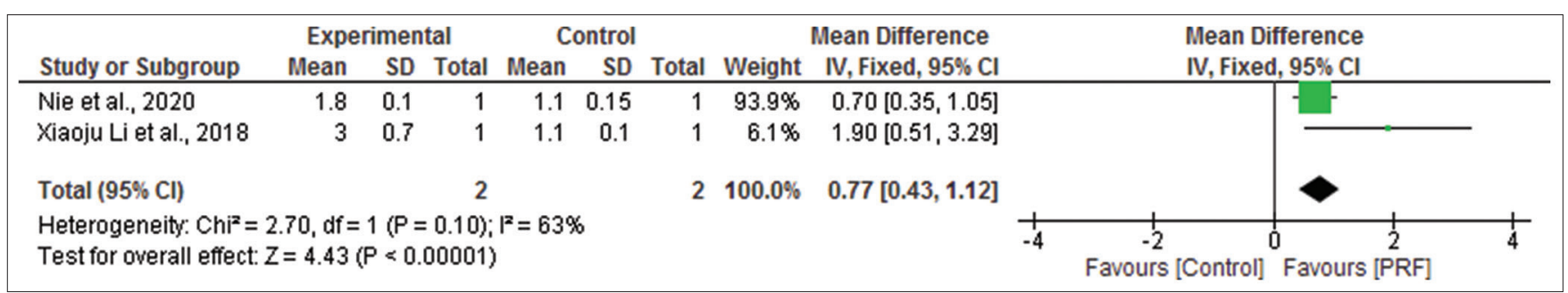

Figure 4: Forest plot of PRF and OCN 


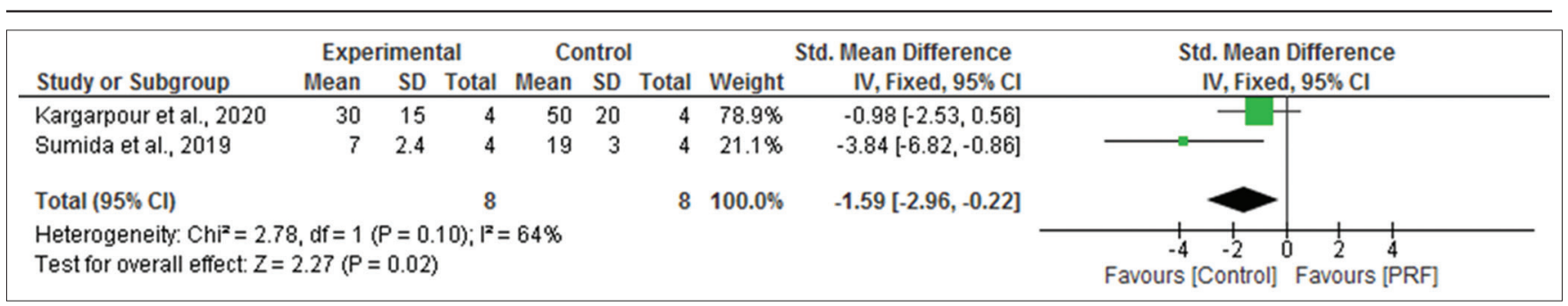

Figure 5: Forest plot of PRF and TRAP

either $\beta$-TCP or PRF alone [15].

\section{Quantitative analysis}

Nine studies were included in the metaregression analysis as shown in Table 1 . The studies were divided into four different outcome parameters, such as ALP, RUNX2, OCN, and TRAP, to assess the effectiveness of PRF in bone osteogenesis.

\section{The alkaline phosphatase test (ALP)}

Bone ALP is a primary regulator of bone mineralization. ALP has a principal function in bone mineralization in the process of bone-forming through hydrolyzing phosphate esters and ALP has been screened during human bone regeneration. In addition, ALP has been categorized as an initial marker for cells osteogenesis [16]. Four experimental studies were analyzed for PRF and bone ALP. The result found that the fixed effect size is $1.40[1.14-1.67] p=0.001, I^{2}=98 \%$. It indicates a significant effect of PRF application with the increase of ALP compared to the control group (Figure 2).

\section{RUNX2}

Runt-related transcription factor 2 (RUNX2) is a transcription factor associated closely with the osteoblast phenotype. RUNX2 is required for the osteoblast progenitor proliferation of osteoblast progenitors and proliferation inductor [17]. Our result showed that the effect size of PRF in RUNX2 is 1.10 $[0.93,1.26] p=0.001, I^{2}=98 \%$. It indicated a significant effect of PRF application with the increase of RUNX2 compared to the control group (Figure 3).

\section{OCN}

$\mathrm{OCN}$ is derived from mature osteoblast and mainly accumulated in the extracellular matrix (ECM) of bones. OPN and OCN have an essential function in bone mineralization and are associated with the differentiation of osteogenesis. They are commonly treated as osteogenesis differentiation markers [18]. Our result showed that the effect size of PRF in OCN is $0.77[0.43,1.12] p=0.001, I^{2}=63 \%$. It is indicated a significant effect of PRF application with the increase of OCN compared to the control group (Figure 4).
Table 1: Studies included in meta-regression

\begin{tabular}{|c|c|c|c|}
\hline Author and Year & $\begin{array}{l}\text { Treatment } \\
\text { comparison }\end{array}$ & $\begin{array}{l}\text { Number of } \\
\text { experiment }\end{array}$ & Result \\
\hline (Nie et al., 2020) & $\mathrm{OCN}$ and OPN & $\mathrm{n}=1$ & $\begin{array}{l}\text { OCN (Mean, SD) } \\
\cdot \text { Control }(1.1,0.1) \\
\cdot \text { L-PRF }(3,0.7) \\
\text { OPN (Mean and standard } \\
\text { deviation) } \\
\cdot \cdot \text { L-PRF }(2.3,0.7) \\
\cdot \text { Control }(1,0.1)\end{array}$ \\
\hline $\begin{array}{l}\text { (Sumida } \\
\text { et al., 2019) }\end{array}$ & $\begin{array}{l}\text { - OPG positive } \\
\text { cells mean } \\
\text { - TRAP-positive } \\
\text { cell scale bars } \\
\text { - ALP mg } \\
\text { - RUNX2 }\end{array}$ & $\begin{array}{l}\text { OPG } n=4, \\
\text { TRAP } n=4, \\
\text { ALP }=3, \\
\text { RUNX2 } n=3\end{array}$ & $\begin{array}{l}\text { OPG positive cells Mean, } 10 \mu \mathrm{m} \\
\text { (Mean, SD) } \\
\cdot \text { PRF }=(170,60) \\
\cdot \text { Control }=(60,20) \\
\text { TRAP positive cell scale bars, } \\
10 \mu \mathrm{m}(\text { Mean, SD) } \\
\cdot \text { PRF }=(7,4,8) \\
\cdot \text { Control }=(19,6) \\
\text { ALP mg (Mean, SD) } \\
\cdot \text { PRF }=(10,6.9) \\
\text { - Control }=(36,5.19) \\
\text { RUNX2 (Mean, SD) } \\
\text { - PRF }(1.2,0.34) \\
\cdot \text { Control }(1.1,0.34)\end{array}$ \\
\hline (Song et al., 2018) & $\begin{array}{l}\text { - ALP activity } \\
\text { nmol/min/mg } \\
\text { protein } \\
\text { - RUNX2 } \\
\text { - OPN } \\
\text { expression }\end{array}$ & $\mathrm{N}=3$ & $\begin{array}{l}\text { ALP Activity nmol/min/mg } \\
\text { protein (Mean, SD) } \\
\cdot \text { PRF }=(85,10) \\
\cdot \text { Control= }(51,10) \\
\text { RUNX2 (Mean, SD) } \\
\cdot \text { PRF }=(1.7,0.2) \\
\cdot \text { Control }=(1.2,0.1) \\
\text { ALP (Mean, SD) } \\
\cdot \text { Control; }(2.8,0.2) \\
\text { - PRF: }(3.7,0.3) \\
\text { OPN (Mean, SD) } \\
14 \text { Days } \\
\cdot \text { PRF }(3.3,3.5) \\
\cdot \text { Control }(2.6,0.1)\end{array}$ \\
\hline (Wong et al., 2021) & $\begin{array}{l}\text { - ALP expression } \\
\text { - RUNX2 }\end{array}$ & $\mathrm{N}=5$ & $\begin{array}{l}\text { ALP expression (Mean, SD) } \\
\text { - PRF }(3.8,0.3) \\
\text { - Control }(1.0,0.1) \\
\text { RUNX2 (Mean, SD) } \\
\text { - PRF }(3.5,0.2) \\
\text { - Control }(0.9,0.3)\end{array}$ \\
\hline $\begin{array}{l}\text { (Kargarpour } \\
\text { et al., 2020) }\end{array}$ & TRAP & $\mathrm{N}=4$ & $\begin{array}{l}\text { TRAP (Mean, SD) } \\
\quad \cdot \text { Control }(50,20) \\
\text { • PRF }(30,15)\end{array}$ \\
\hline $\begin{array}{l}\text { (Thanasrisuebwong } \\
\text { et al., 2020) }\end{array}$ & ALP (microgram) & $\mathrm{N}=2$ & $\begin{array}{l}\text { ALP microgram (Mean, SD) } \\
\text { - Control }(0.006,0.007) \\
\text { - Yellow PRF }(0.018,0.019) \\
\text { - Red PRF }(0.015,0.018)\end{array}$ \\
\hline $\begin{array}{l}\text { (Xiaoju Li } \\
\text { et al., 2018) }\end{array}$ & $\begin{array}{l}\cdot \text { RUNX2 } \\
\cdot \text { OCN }\end{array}$ & $\mathrm{N}=1$ & $\begin{array}{l}\text { RUNX2 (Mean, SD) } \\
\cdot \text { PRF }=(1.4,0.2) \\
\cdot \text { Control= }(1.6,0.2) \\
\text { OCN }(\text { Mean, SD) } \\
\cdot \text { PRF }=(1.8,0.1) \\
\cdot \text { Control }=(1.1,0.15)\end{array}$ \\
\hline $\begin{array}{l}\text { (Ghaznavi } \\
\text { et al., 2019) }\end{array}$ & ALP & $\mathrm{N}=1$ & $\begin{array}{l}\text { ALP (Mean, SD) } \\
\text { • Control }(5.5,0.2) \\
\text { - PRF }(5.8,0.2)\end{array}$ \\
\hline $\begin{array}{l}\text { (Duan } \\
\text { et al., 2018) }\end{array}$ & RUNX2 & $\mathrm{N}=3$ & $\begin{array}{l}\text { RUNX2 (Mean, SD) } \\
\text { Control }=(1.0,0.01) \\
\text { PRF }=(7.9,1)\end{array}$ \\
\hline
\end{tabular}

\section{TRAP}

Tartrate-resistant acid phosphatase (TRAP) is mainly expressed in bone through osteoclasts; it is also found in osteoblast and osteoblasts. TRAP agitates mesenchymal lineage cells differentiation, that 
is, osteoblasts and adipocytes progenitors [19]. Our analysis showed that the effect size of PRF in TRAP is $-1.59[-2.96,-0.22] p=0.001,12=64 \%$. It indicates that there is significant effect of PRF application with the declining number of TRAP compared to the control group.

\section{Conclusion}

PRF combined with other materials showed more promising results rather than PRF only. Otherwise, in the assessment of PRF only, it was found that PRF has a significant effect in accelerating bone osteogenesis. PRF increases the alkaline phosphatase test (ALP), RUNX2, and OCN and decreases tartrateresistant acid phosphatase (TRAP).

\section{References}

1. Kiernan C, Knuth C, Farrell E. Endochondral Ossification: Recapitulating Bone Development for Bone Defect Repair. Amsterdam, Netherlands: Elsevier Inc.; 2018.

2. Agrawal M, Agrawal V. Platelet rich fibrin and its applications in dentistry-a review article. Natl J Med Dent Res. 2014;2(3):51-8.

3. Calori GM, Mazza E, Colombo M, Ripamonti C. The use of bonegraft substitutes in large bone defects: Any specific needs? Injury. 2011;42(2):S56-63. https://doi.org/10.1016/j.injury.2011.06.011 PMid:21752369

4. Kanakamedala A, Ari G, Sudhakar U, Vijayalakshmi $R$, Ramakrishnan T, Emmadi P. Treatment of a furcation defect with a combination of platelet-rich fibrin (PRF) and bone graft-a case report. ENDO. 2009;3(2):127-35.

5. Najeeb S, Khurshid Z, Agwan MA, Ansari SA, Zafar MS, Matinlinna JP. Regenerative potential of platelet rich fibrin (PRF) for curing intrabony periodontal defects: A systematic review of clinical studies. Tissue Eng Regen Med. 2017;14(6):735-42. https://doi.org/10.1007/s13770-017-0079-5

PMid:30603523

6. Liberati A, Altman DG, Tetzlaff J, Mulrow C, Gøtzsche PC loannidis JP, et al. The PRISMA statement for reporting systematic reviews and meta-analyses of studies that evaluate healthcare interventions: Explanation and elaboration. BMJ. 2009;339:b2700. https://doi.org/10.1136/bmj.b2700

PMid:19622552

7. Sumida R, Maeda T, Kawahara I, Yusa J, Kato Y. Platele-trich fibrin increases the osteoprotegerin/receptor activator of nuclear factorkB ligand ratio in osteoblasts. Exp Ther Med. 2019;18(1):358-65. https://doi.org/10.3892/etm.2019.7560 PMid:31258673

8. Dohle E, El Bagdadi K, Sader R, Choukroun J, Kirkpatrick CJ, Ghanaati S. Platelet-rich fibrin-based matrices to improve angiogenesis in an in vitro co-culture model for bone tissue engineering. J Tissue Eng Regen Med. 2018;12(3):598-610. https://doi.org/10.1002/term.2475

PMid:28509340
9. Kargarpour Z, Nasirzade J, Strauss FJ, Di Summa F, Hasannia S, Müller HD, et al. Platelet-rich fibrin suppresses in vitro osteoclastogenesis. J Periodontol. 2020;91(3):413-21. https://doi.org/10.1002/JPER.19-0109 PMid:31381154

10. Zhang K, Barragan-Adjemian C, Ye L, Kotha S, Dallas M, Lu Y, et al. E11/gp38 selective expression in osteocytes: Regulation by mechanical strain and role in dendrite elongation. Mol Cell Biol. 2006;26(12):4539-52. https://doi.org/10.1128/ MCB.02120-05

PMid: 16738320

11. Wong PC, Wang $\mathrm{CY}$, Jang JS, Lee $\mathrm{CH}$, Wu JL. Large-pore platelet-rich fibrin with a $\mathrm{mg}$ ring to allow mc3t3-e1 preosteoblast migration and to improve osteogenic ability for bone defect repair. Int J Mol Sci. 2021;22(8):4022. https://doi.org/10.3390/ ijms22084022

PMid:33919677

12. Thanasrisuebwong $P$, Kiattavorncharoen $S$, Surarit $R$, Phruksaniyom C, Ruangsawasdi N. Red and yellow injectable platelet-rich fibrin demonstrated differential effects on periodontal ligament stem cell proliferation, migration, and osteogenic differentiation. Int J Mol Sci. 2020;21(14):5153. https://doi.org/10.3390/ijms21145153

PMid:32708242

13. Wong CC, Liao JH, Sheu SY, Lin PY, Chen CH, Kuo TF. Novel transplant of combined platelet-rich fibrin Releasate and bone marrow stem cells prevent bone loss in Ovariectomized osteoporotic mice. BMC Musculoskelet Disord. 2020;21(1):527. https://doi.org/10.1186/s12891-020-03549-y

PMid:32770974

14. Ghaznavi D, Babaloo A, Shirmohammadi A, Zamani AR, Azizi M, Rahbarghazi R, et al. Advanced platelet-rich fibrin plus gold nanoparticles enhanced the osteogenic capacity of human mesenchymal stem cells. BMC Res Notes. 2019;12(1):721. https://doi.org/10.1186/s13104-019-4750-x

PMid:3168501

15. Yilmaz D, Dogan N, Ozkan A, Sencimen M, Ora BE, Mutlu I. Effect of platelet rich fibrin and beta tricalcium phosphate on bone healing. A histological study in pigs. Acta Cir Bras. 2014;29(1):59-65. https://doi.org/10.1590/ S0102-86502014000100009

PMid:24474179

16. Golub E, Battaglia K. The role of alkaline phosphatase in osteogenesis. J Exp Med. 1951;93(5):415-26. https://doi. org/10.1084/jem.93.5.415

17. Kawane T, Qin X, Jiang Q, Miyazaki T, Komori H, Yoshida CA, et al. Runx2 is required for the proliferation of osteoblast progenitors and induces proliferation by regulating Fgfr2 and Fgfr3. Sci Rep. 2018;8(1):13551. https://doi.org/10.1038/ s41598-018-31853-0 PMid:30202094

18. Zhang $\mathrm{Y}$, Gong H, Sun $\mathrm{Y}$, Huang $\mathrm{Y}$, Fan Y. Enhanced osteogenic differentiation of MC3T3-E1 cells on grid-topographic surface and evidence for involvement of YAP mediator. J Biomed Mater Res A. 2016;104(5):1143-52. https://doi.org/10.1002/ jbm.a.35648 PMid:26748630

19. Gradin P, Hollberg K, Cassady AI, Lång P, Andersson G. Transgenic overexpression of tartrate-resistant acid phosphatase is associated with induction of osteoblast gene expression and increased cortical bone mineral content and density. Cells Tissues Organs. 2012;196(1):68-81. https://doi. org/10.1159/000330806

PMid:22248481 